\title{
Constructing Functional Ionic Membrane Surface by Electrochemically Mediated Atom Transfer Radical Polymerization
}

\author{
Fen Ran, Dan Li, and Jiayu Wu \\ State Key Laboratory of Advanced Processing and Recycling of Nonferrous Metals, Lanzhou University of Technology, \\ Lanzhou 730050, China
}

Correspondence should be addressed to Fen Ran; ranfen@163.com

Received 22 August 2016; Accepted 5 September 2016

Academic Editor: Qiang Wei

Copyright (c) 2016 Fen Ran et al. This is an open access article distributed under the Creative Commons Attribution License, which permits unrestricted use, distribution, and reproduction in any medium, provided the original work is properly cited.

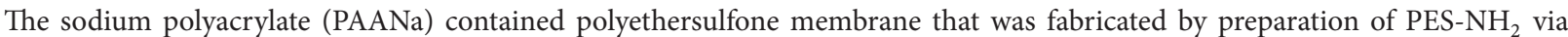
nonsolvent phase separation method, the introduction of bromine groups as active sites by grafting $\alpha$-Bromoisobutyryl bromide, and surface-initiated electrochemically atom transfer radical polymerization (SI-eATRP) of sodium acrylate (AANa) on the surface of PES membrane. The polymerization could be controlled by reaction condition, such as monomer concentration, electric potential, polymerization time, and modifier concentration. The membrane surface was uniform when the monomer concentration was $0.9 \mathrm{~mol} / \mathrm{L}$, the electric potential was $-0.12 \mathrm{~V}$, the polymerization time was $8 \mathrm{~h}$, and the modifier concentration was $2 \mathrm{wt} . \%$. The membrane showed excellent hydrophilicity and blood compatibility. The water contact angle decreased from $84^{\circ}$ to $68^{\circ}$ and activated partial thromboplastin increased from $51 \mathrm{~s}$ to $84 \mathrm{~s}$ after modification of the membranes.

\section{Introduction}

Interfacial properties and interactions with cells and biological fluids play a vital role in the applications of polymers as biomaterials [1], and it is of great importance to control and manipulate the surface $[2,3]$. It is well known that polymeric materials are widely used in the biomedical field such as cellulose acetate (CA), polymethylmethacrylate (PMMA), polyacrylonitrile (PAN), ethylene vinyl alcohol copolymer (EVAL), polyvinyl alcohol (PVA), polysulfone (PSf), and polyethersulfone (PES) [4]. Among these materials used in the biomedical field, polyethersulfone (PES) is one of the most important polymeric materials and is widely used as biomaterial for good chemical, thermal and hydrolytic stability, wide $\mathrm{pH}$ applicable scope, and oxidation resistance. However, blood compatibility and hydrophilicity of PES are not ideal because of intrinsic hydrophobicity.

To improve hydrophilicity and biocompatibility of PES membranes, several polymers were used for surface modification over the past two decades, such as heparin [5], heparin-like polymers [6], polyethylene glycol (PEG) [7], and zwitterionic polymers [8]. Furthermore, many methods including coating method [9], UV grafting [10], plasma treatment [11], and surface-initiated atom transfer radical polymerization (SI-ATRP) [12] have been employed for immobilizing some functional groups onto PES membrane surfaces. ATRP-based method is one of the most popular methods of these modification techniques.

Controlled living radical polymerization has been researched in the past few decades. Matyjaszewski et al. reported the ATRP firstly. In the ATRP system, oxidation state metal halide salt $\mathrm{Cu}^{\mathrm{I}} \mathrm{L}^{+}$take halogen atoms from organic halide in the $\mathrm{R}-\mathrm{X}$ to produce high oxidation state metal halide $\mathrm{X}-\mathrm{Cu}^{\mathrm{II}} \mathrm{L}^{+}$and propagating radicals $[\mathrm{R} \bullet]$ and $[\mathrm{R} \bullet$ induced monomer polymerization to produce $\mathrm{R}-\mathrm{Mn} \bullet$; R-Mn• take halogen atoms afresh to produce $\mathrm{R}-\mathrm{Mn}-\mathrm{X}$ and $\mathrm{Cu}^{\mathrm{I}} \mathrm{L}^{+}[13,14]$. Radical polymerization at the same time is accompanied with the reversible and balanced reaction between free radical activity and organic macromolecular halide dormant species. ATRP is widely used for the synthesis of block and graft polymers based on a wide variety of monomers [15-17]. However, the association of $\mathrm{X}$ - to $\mathrm{Cu}^{\mathrm{II}} \mathrm{L}^{2+}$ diminishes the concentration 
of deactivator $\mathrm{X}-\mathrm{Cu}^{\mathrm{II}} \mathrm{L}^{+}$, and ATRP aqueous has a relatively large ratio of activators $\left(\mathrm{Cu}^{\mathrm{I}} \mathrm{L}^{+}\right)$and deactivators $\left(\mathrm{X}-\mathrm{Cu}^{\mathrm{II}} \mathrm{L}^{+}\right)$, which provides a high $[\mathrm{R} \bullet$ ] and fast polymerizations [18, 19], so it is difficult to achieve polymerization control and the targeted degree of polymerization via ATRP [20, 21]. Matyjaszewski et al. solved above problems by introducing electrochemistry in ATRP technology which was named electrochemically atom transfer radical polymerization (eATRP). eATRP system includes solvent, monomer, initiator, and catalyst $\mathrm{Cu}^{\mathrm{II}} \mathrm{L}^{2+}$. The onset of polymerization begins only when sufficient potential is applied to the cathode so that reduction of $\mathrm{Cu}^{\mathrm{II}} \mathrm{L}^{2+}$ to $\mathrm{Cu}^{\mathrm{I}} \mathrm{L}^{+}$occurs at the working electrode. The magnitude of potential can be appropriately chosen to achieve continuous (re)generation of a small quantity of $\mathrm{Cu}^{\mathrm{I}} \mathrm{L}^{+}$ and consequently dictate the $[\mathrm{R} \bullet]$. A living polymerization process is ensured by the combination of a low [R•] and high $\left[\mathrm{Cu}^{\mathrm{II}} \mathrm{L}^{2+}\right] /\left[\mathrm{Cu}^{\mathrm{I}} \mathrm{L}^{+}\right]$ratio $[22,23]$. Based on eATRP, $\mathrm{Li}$ et al. achieved surface polymerization by surface-initiated electrochemically atom transfer radical polymerization (SIeATRP) firstly to graft functional polymer brushes on metal substrate [24]. In SI-eATRP system, $\mathrm{Cu}^{\mathrm{II}} \mathrm{L}^{2+}$ catalyst can be electrochemically reduced to $\mathrm{Cu}^{\mathrm{I}} \mathrm{L}^{+}$activators to start a controlled polymerization [25]. Nevertheless, SI-eATRP method was not used for surface modification of polymer membrane.

In this study, PAANa was covalently grafted from PES/PES- $\mathrm{NH}_{2}$ membrane by SI-eATRP method to improve the blood compatibility and hydrophilicity of PES membrane. The growth of polymer brushes was controlled by monomer concentration, electric potential, polymerization time, and modifier concentration. The hydrophilicity and blood compatibility of the modified membrane were investigated by water contact angle and activated partial thromboplastin time, respectively.

\section{Experimental}

2.1. Chemicals. Polyethersulfone (PES, Ultrason E6020P) and N, N-dimethyl acetamide (DMAc, 93\%) were purchased from BASF, Germany. Nitric acid $\left(\mathrm{HNO}_{3}, 65 \%\right)$ and hydrochloric acid $(\mathrm{HCl}, 37 \%)$ were purchased from GuoYao Chemical Reagent Company. Cupric bromide $\left(\mathrm{CuBr}_{2}\right.$, $98 \%)$ and stannous chloride $\left(\mathrm{SnCl}_{2}, 98 \%\right)$ were purchased from Shanghai Zhongtai Chemical Reagent Company. Sulfuric acid $\left(\mathrm{H}_{2} \mathrm{SO}_{4}, 98 \%\right)$ was purchased from Changliao Chemical Reagent Company. Triethylamine (TEA) was purchased from DaMao Chemical Reagent Factory. Ethanol $\left(\mathrm{CH}_{3} \mathrm{CH}_{2} \mathrm{OH}\right)$ and anhydrous diethyl ether $\left(\mathrm{C}_{4} \mathrm{H}_{10} \mathrm{O}\right)$ were purchased from KeLong Chemical Reagent Factory. Dibromo butyryl $\alpha$ Bromoisobutyryl bromide $\left(\mathrm{C}_{4} \mathrm{H}_{6} \mathrm{Br}_{2} \mathrm{O}, 98 \%\right)$ and tetramethyl ethylenediamine (TMEDA) were purchased from Aladdin Reagent.

2.2. Amination of PES. Nitric acid $(30 \mathrm{~mL})$ and sulfuric acid $(40 \mathrm{~mL})$ were mixed in $250 \mathrm{~mL}$ flask, and then PES $(10 \mathrm{~g})$ was added slowly into the flask when the mixture refrigerated to room temperature. After continuous stirring at $65^{\circ} \mathrm{C}$ for $6 \mathrm{~h}$, the resulting solution was then washed with deionized water several times. Granular PES-NO $\mathrm{NO}_{2}$ was obtained after vacuum drying for $24 \mathrm{~h} .20 \mathrm{~g}(0.089 \mathrm{~mol})$ stannous chloride was dissolved into $20 \mathrm{~g}, 37 \% \mathrm{HCl}$ in a flask, followed by adding $50 \mathrm{~mL}$ ethyl alcohol [26]. Then $3 \mathrm{~g}$ grinded PES- $\mathrm{NO}_{2}$ was added slowly into the flask after the mixture was stirred at $65^{\circ} \mathrm{C}$ for $15 \mathrm{~min}$. The mixture was left to react at $65^{\circ} \mathrm{C}$ for another $6 \mathrm{~h}$. The resulting precipitate was then washed with deionized water several times when filtering. Brown PES$\mathrm{NH}_{2}$ was obtained after vacuum drying for $24 \mathrm{~h}$.

\subsection{Preparation of PES/PES- $\mathrm{NH}_{2}$ Membrane. PES/PES-NH} membrane was prepared via classical phase inversion method. Casting solution consists of different amounts of PES, corresponding to different amounts of PES- $\mathrm{NH}_{2}$ as modifier in $8.2 \mathrm{~mL}$ DMAc as solvent, and was stirred for $12 \mathrm{~h}$. The resultant uniform solution was degassed under vacuum at room temperature for $15 \mathrm{~min}$. After that, the casting solution was daubed on a glass substrate, followed by well gluing film machine for homogeneous thickness. Finally, the glass with even solution was thrown into deionized water, and then the casting solution became membrane quickly. The membranes were immersed in deionized water at room temperature for $24 \mathrm{~h}$ to remove residual DMAc. Next, Br group was introduced onto the surface of membranes as active sites by nucleophilic substitution reaction between PES- $\mathrm{NH}_{2}$ and $\alpha$-Bromoisobutyryl bromide. The process is as follows: $50 \mathrm{mg}$ PES/PES- $\mathrm{NH}_{2}$ membranes were rinsed in a beaker containing $54 \mu \mathrm{L}$ triethylamine and $30 \mathrm{~mL}$ diethyl ether in ice-water bath. Then, another solution including $0.39 \mathrm{~mol}$ $\alpha$-Bromoisobutyryl bromide and $20 \mathrm{~mL}$ diethyl ether was added into previous solution at a rate of one drop per second. The membranes were stirred for another $0.5 \mathrm{~h}$ in an ice-water bath after dropping $\alpha$-Bromoisobutyryl bromide. The resultant solution was stirred at room temperature for $12 \mathrm{~h}$ and subsequently was washed successively by diethyl ether, methylbenzene, methyl alcohol, and deionized water. $\mathrm{PES} / \mathrm{PES}-\mathrm{Br}$ membranes were obtained after drying under vacuum for $12 \mathrm{~h}$.

2.4. SI-eATRP Induced Sodium Acrylate Polymerization. The reaction system includes working electrode, counter electrode, and saturated calomel electrode. Electrolyte includes monomer AANa, ligand tetramethylethylenediamine, catalyst copper bromide $\mathrm{CuBr}_{2}$, and electrolyte benzyltributylammonium chloride BBAC. On the specific scan potential, polymerization of AANa was carried out under $\mathrm{Cu}^{\mathrm{II}} / \mathrm{Cu}^{\mathrm{I}}$ redox-catalyst system. Polymer brushes were grafted on the membrane surface. The scheme diagram of preparation process of the M-PAANa is shown in Scheme 1.

2.5. Characterization. Fourier transform infrared (FTIR) spectra were recorded on a Nicolet 560 (Spectrometer, USA). Morphology images were observed by scanning electron microscopy (SEM) using S-2500C (Hitachi, Japan). Static water contact angles (WCA) were measured by PHS-3C (Precision science co., ShangHai, China). X-ray photoelectroscopy (XPS) was measured by XSAM800 (KRATOS co., Britain). $1 \mathrm{~cm}^{2}$ of prepared membrane was pasted on the 


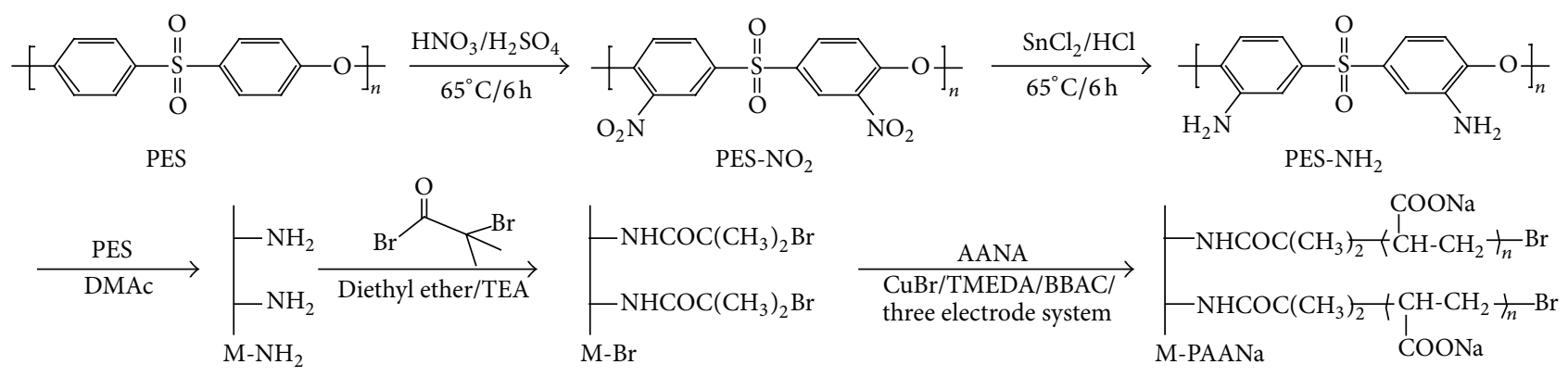

SCHEME 1: Schematic diagram for preparation process of the M-PAANa.

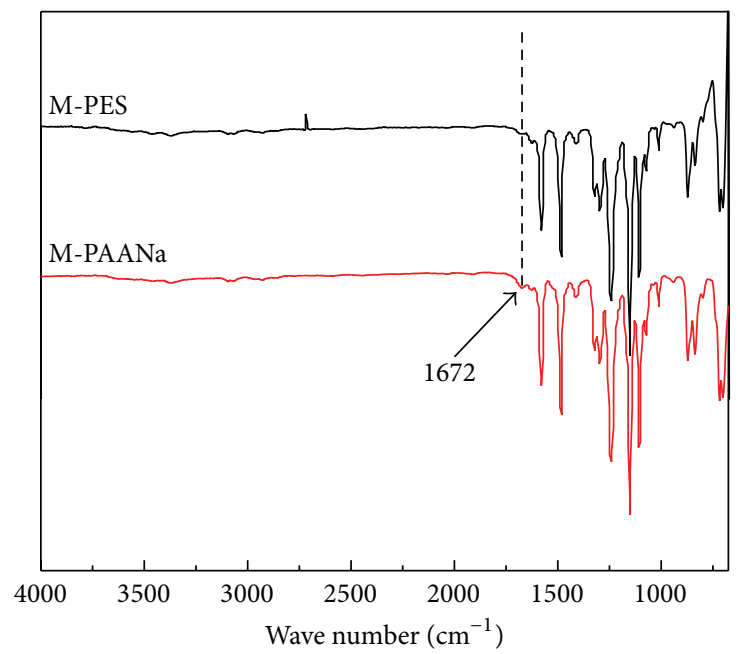

FIGURE 1: ATR-FTIR spectra for the M-PES and M-PAANa.

glass and was scanned by anatomic force microscopy (AFM) to obtain the surface morphology and three dimensional structure (scanning range was $10 \mu \mathrm{m} \times 10 \mu \mathrm{m}$ ) of the prepared membranes.

2.6. Grafting Yield. The grafting yield of PAANa brushes on the M-PES was calculated by (1), where $m_{0}(\mathrm{mg})$ and $m_{1}(\mathrm{mg})$ are weight before and after grafting PAANa and $A$ is the area of membrane. The last mean result was obtained by three measurements.

$$
\mathrm{GY}=\frac{m_{1}-m_{0}}{A}
$$

2.7. Hydrophilicity Measurements. The hydrophilic of membrane surface was usually denoted by static water contact angle (WCA). Static water contact angle is a way to characterize the wettability properties of membrane surface [27]. $5 \mu \mathrm{L}$ water was dripped on the surface of the membrane; at the same time, drip pictures were obtained by lens of microscope and camera, and then the angles were calculated by digital image processing. The last mean result was obtained by three different sites measurements.

2.8. Clotting Time. Antithrombogenicity of the membrane was evaluated by activated partial thromboplastin (APTT), which was measured by an automated blood coagulation analyzer CA-50 (Sysmex Corporation, Kobe, Japan). The test method is as follows: $0.5 \mathrm{~cm} \times 0.5 \mathrm{~cm}$ of membrane was immersed in $2 \mathrm{~mL}$ phosphate buffer saline (PBS, $\mathrm{PH}$ $=7.4$ ) solution for $1 \mathrm{~h}$, and then PBS was removed and $0.1 \mathrm{~mL}$ platelet-poor plasma (PPP) was added. $50 \mu \mathrm{L}$ PPP was inhaled in a test cup after incubation at $37^{\circ} \mathrm{C}$ for $30 \mathrm{~min}$, and $50 \mu \mathrm{L}$ TT/APTT reagent was added in the test cup at $37^{\circ} \mathrm{C}$, followed by incubation for $3 \mathrm{~min}$. Then clotting time was measured and the last mean result was obtained by three measurements.

\section{Results and Discussion}

The preparation of the M-PAANa is shown in Scheme 1, which mainly included three steps: (i) nitrogroup was introduced to PES macromolecule and transformed to amino to obtain amino-modified PES macromolecules (PES-NH $\mathrm{N}_{2}$ ); (ii) PES- $\mathrm{NH}_{2}$ and PES were blended in a certain proportion and proceeded to phase separation to achieve $\mathrm{NH}_{2}$-grafted PES membrane $\left(\mathrm{M}-\mathrm{NH}_{2}\right)$, which was then immersed in $\alpha$-Bromoisobutyryl bromide to acquire membrane initiator (M-Br); and (iii) finally PAANa modified PES membrane (M-PAANa) was prepared by the SI-eATRP method, which was carried out in a three electrode system by using an electrochemical work station.

Figure 1 shows the ATR-FTIR spectra of the pristine PES membrane (M-PES) and M-PAANa. Compared with the M-PES, the M-PAANa showed a new peak at $1672 \mathrm{~cm}^{-1}$, 


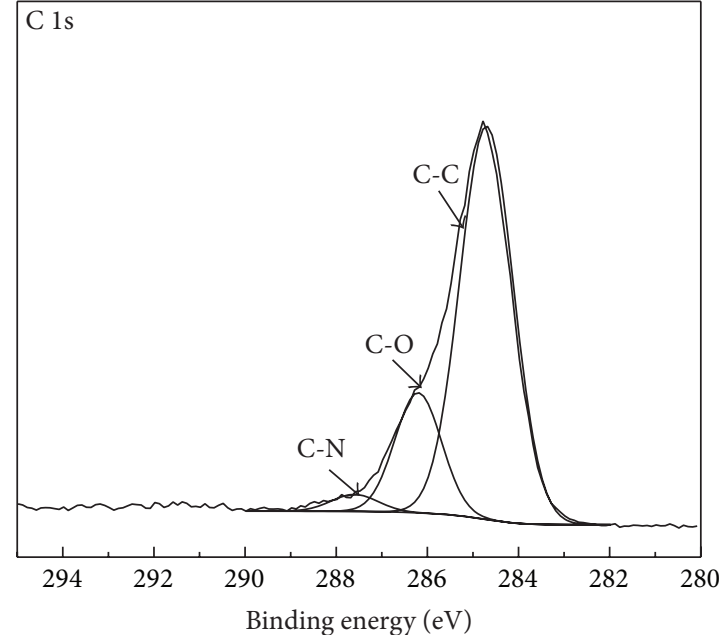

(a)

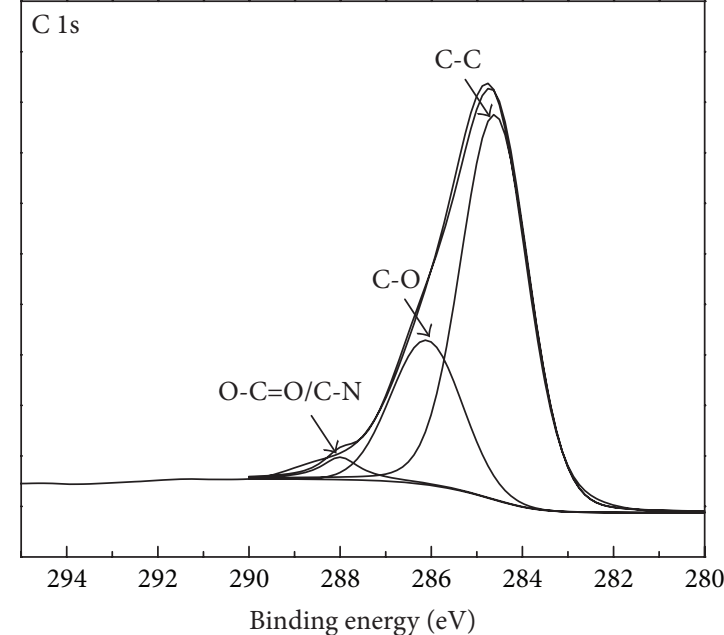

(b)

FIgURE 2: The XPS spectra of C 1s for (a) M-PES and (b) M-PAANa.

which was contributed to the antisymmetric stretching vibration band of the carboxyl on AANa structure. These results indicate that PAANa chains have been grafted on the M-PES membrane.

XPS was used to analyze the change of surface compositions of membranes. The XPS spectra of C 1s core-level spectrum are shown in Figure 2. By comparing the XPS spectra between the M-PES and M-PAANa, there were the same peaks of $\mathrm{C}-\mathrm{O}$ at $286.1 \mathrm{eV}, \mathrm{C}-\mathrm{C}$ at $284.6 \mathrm{eV}$, and $\mathrm{C}-\mathrm{N}$ $(\mathrm{C}=\mathrm{O})$ at $288.0 \mathrm{eV}$ at both M-PES and M-PAANa, while the M-PAANa showed a higher peak of $\mathrm{C}=\mathrm{O}$ at $288.0 \mathrm{eV}$ which was contributed to carboxyl of AANa, also indicating that the PAANa chains were grafted on the membrane.

The AFM images of the M-PES and the M-PAANa are shown in Figure 3. It can be found that the latter sample had an evident peak-valley structure, and there were plenty of particles $(20-50 \mathrm{~nm})$ on the surface of M-PAANa compared with M-PES. The roughness $\mathrm{Ra}$ increased from $14.4 \mathrm{~nm}$ of M-PES (Figure 3(a)) to $29.4 \mathrm{~nm}$ of M-PAANa (Figure 3(b)), which was attributed to the PAANa brushes grafted on PES membrane.

As shown in Figure 4, when the monomer concentration was 0.09 and $0.9 \mathrm{~mol} / \mathrm{L}$, the corresponding grafting yield was 0.01 and $0.36 \mathrm{mg} / \mathrm{cm}^{2}$, respectively, at the electric potential of $-0.12 \mathrm{~V}$ for grafting time of $8 \mathrm{~h}$. It is found that the grafting yield of the former was so much lower than the latter, which may be the cause that too little monomer was scattered in the electrolyte which is difficultly grafted to the membrane surface, agreeing with the SEM results. We can see from the SEM images that there were apparent polymer nanoparticles grafted on the surface of the membrane; and the latter sample had more and bigger nanoparticles (about $20 \mathrm{~nm}$ ) compared with that of former sample (about $3 \mathrm{~nm}$ ). This indicates that higher concentration of monomer in the SI-eATRP system would show higher grafting degree of the polymer chain and thus thicker polymer coating.
Figure 5 shows the SEM images of M-PAANa prepared with different electric potential of $-0.08,-0.12$, and $-0.2 \mathrm{~V}$. By calculation, we found that their corresponding grafting yields were $0.11,0.36$, and $0.24 \mathrm{mg} / \mathrm{cm}^{2}$ at the grafting time of $8 \mathrm{~h}$, modifier concentration was $2 \mathrm{wt} . \%$, and the monomer concentration was $0.9 \mathrm{~mol} / \mathrm{L}$. It can be also seen from the figure that distribution of nanoparticles was uniform and the amount of nanoparticles agreed with the result from grafting yield.

The M-PAANa was also prepared by controlling the polymerization time from $15 \mathrm{~min}$ to $8 \mathrm{~h}$. The grafting yields were increased from 0.04 to $0.12,0.3$, and $0.36 \mathrm{mg} / \mathrm{cm}^{2}$ when the reaction time increased from $15 \mathrm{~min}$ to $0.5,1$, and $8 \mathrm{~h}$, respectively. Figure 6 presents the SEM images of $\mathrm{M}$ PAANa prepared at different grafting time. It can be seen from the figure that the amount of nanoparticles grafted on the membrane surface increased obviously with the reaction time. In addition, there was no further obvious increase of grafted polymer through further prolonging reaction time after $1 \mathrm{~h}$.

The modifier concentration during the membrane preparation process also plays an important role in controlling the graft degree. Figure 7 shows the SEM images of M-PAANa by different modifier concentrations of $0.8,2$, and $5 \mathrm{wt} . \%$. As shown in the picture too low modifier concentration (0.8 wt.\%) resulted in the low graft degree of the polymer brushes; and too high modifier concentration (5 wt.\%) generated many macrovoids on the membrane surface. Moreover, their corresponding grafting yields were calculated to be 0.07 , 0.36 , and $-0.02 \mathrm{mg} / \mathrm{cm}^{2}$, consistent with the result obtained in the SEM characterization.

To sum up, the grafting of ion polymer chains on membrane surface can be carried out by SI-eATRP method, and the density and length of PAANa brushes can be easily controlled by the polymerization condition, such as monomer concentration, electric potential, time of SI-eATRP reaction, and modifier concentration. 


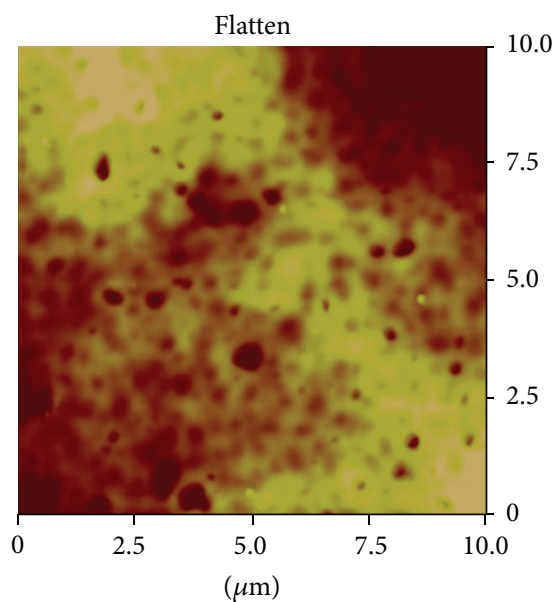

Digital instruments: nanoscope

Scan size: $10.00 \mu \mathrm{m}$

Scan rate: $1.001 \mathrm{~Hz}$

Number of samples: 256

Image data: height

Data scale: $200.0 \mathrm{~nm}$

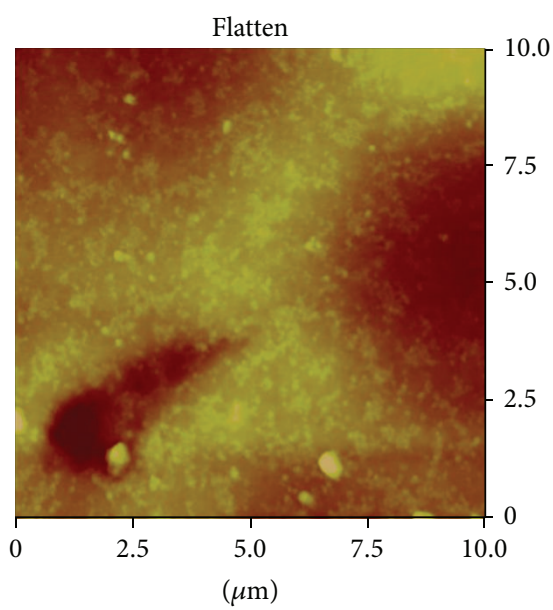

Digital instruments: nanoscope

Scan size: $10.00 \mu \mathrm{m}$

Scan rate: $1.001 \mathrm{~Hz}$

Number of samples: 256

Image data: height

Data scale: $300.0 \mathrm{~nm}$
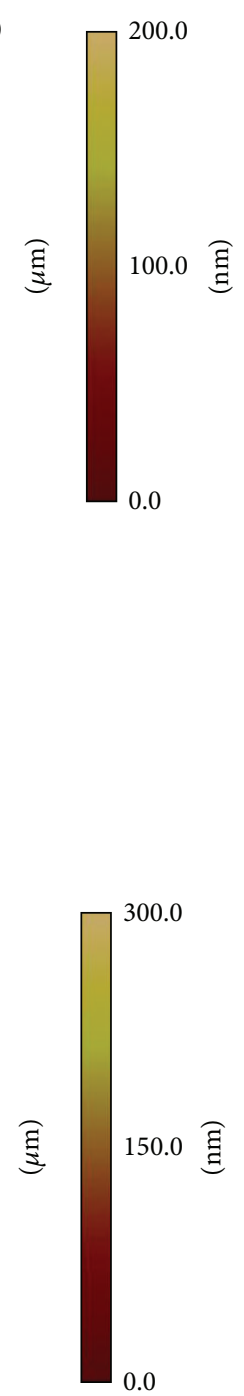

The hydrophilicity of membrane surface was characterized by static water contact angle, which was used to evaluate the wettability of membrane surface. As is shown in Figure 8, the contact angle decreased from $84^{\circ}$ of M-PES to $68^{\circ}$ of MPAANa, which was contributed to the hydrophilic carboxyl of AANa. The APTTs were further measured to study the blood compatibility of the modified membrane, as shown in Table 1. It was found that the blood clotting time of $\mathrm{M}$ PAANa increased to $84 \mathrm{~s}$ compared with that of the pristine PES membrane, that is, $51 \mathrm{~s}$. Then enhancement of blood compatibility is because of (i) increase of hydrophilicity of
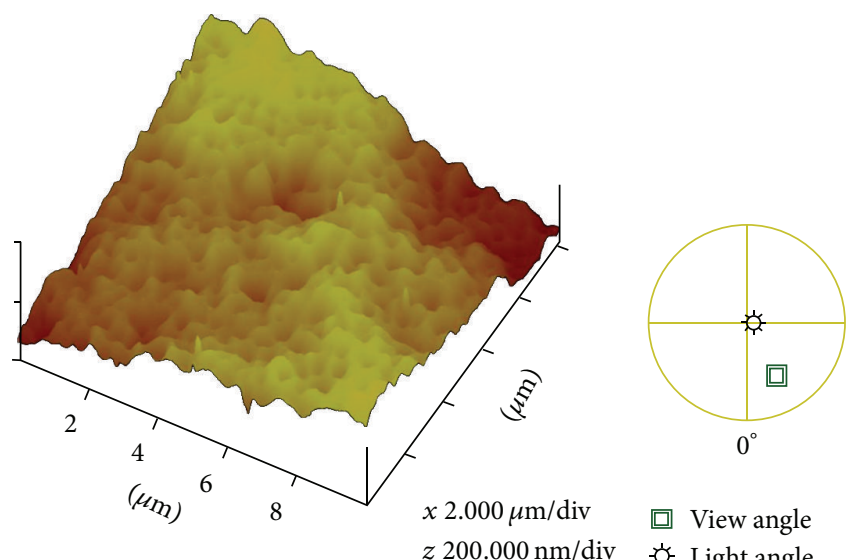

Digital instruments: nanoscope

Scan size: $10.00 \mu \mathrm{m}$

Scan rate: $1.001 \mathrm{~Hz}$

Number of samples: 256

Image data: height

Data scale: $200.0 \mathrm{~nm}$

(a)
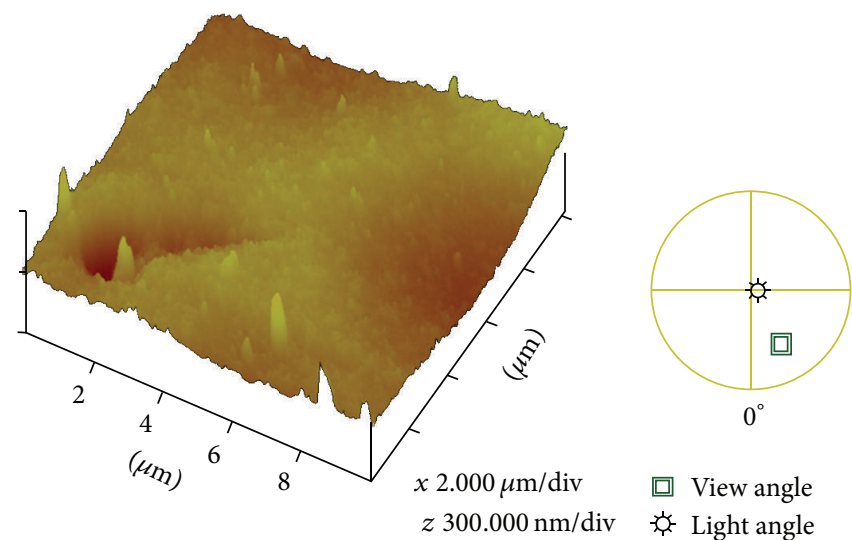

View angle

Light angle

Digital instruments: nanoscope

Scan size: $10.00 \mu \mathrm{m}$

Scan rate: $1.001 \mathrm{~Hz}$

Number of samples: 256

Image data: height

Data scale: $300.0 \mathrm{~nm}$

(b)

Figure 3: AFM images of (a) M-PES and (b) M-PAANa.

the membrane surface and (ii) the grafting of ionic chain on the surface. Based on these results, we can conclude that the grafting method via SI-eATRP method is an effective approach to modify the polymer membranes to improve the surface properties, such as blood compatibility. 

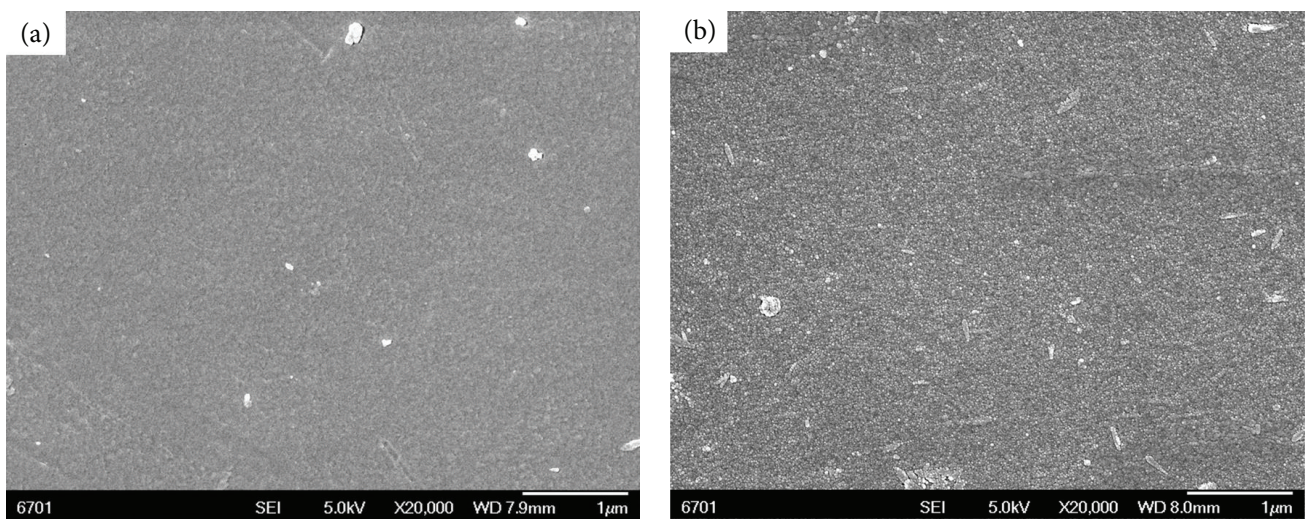

FIGURE 4: SEM images of M-PAANa modified by different monomer concentration: (a) $0.09 \mathrm{~mol} / \mathrm{L}$ and (b) $0.9 \mathrm{~mol} / \mathrm{L}$.
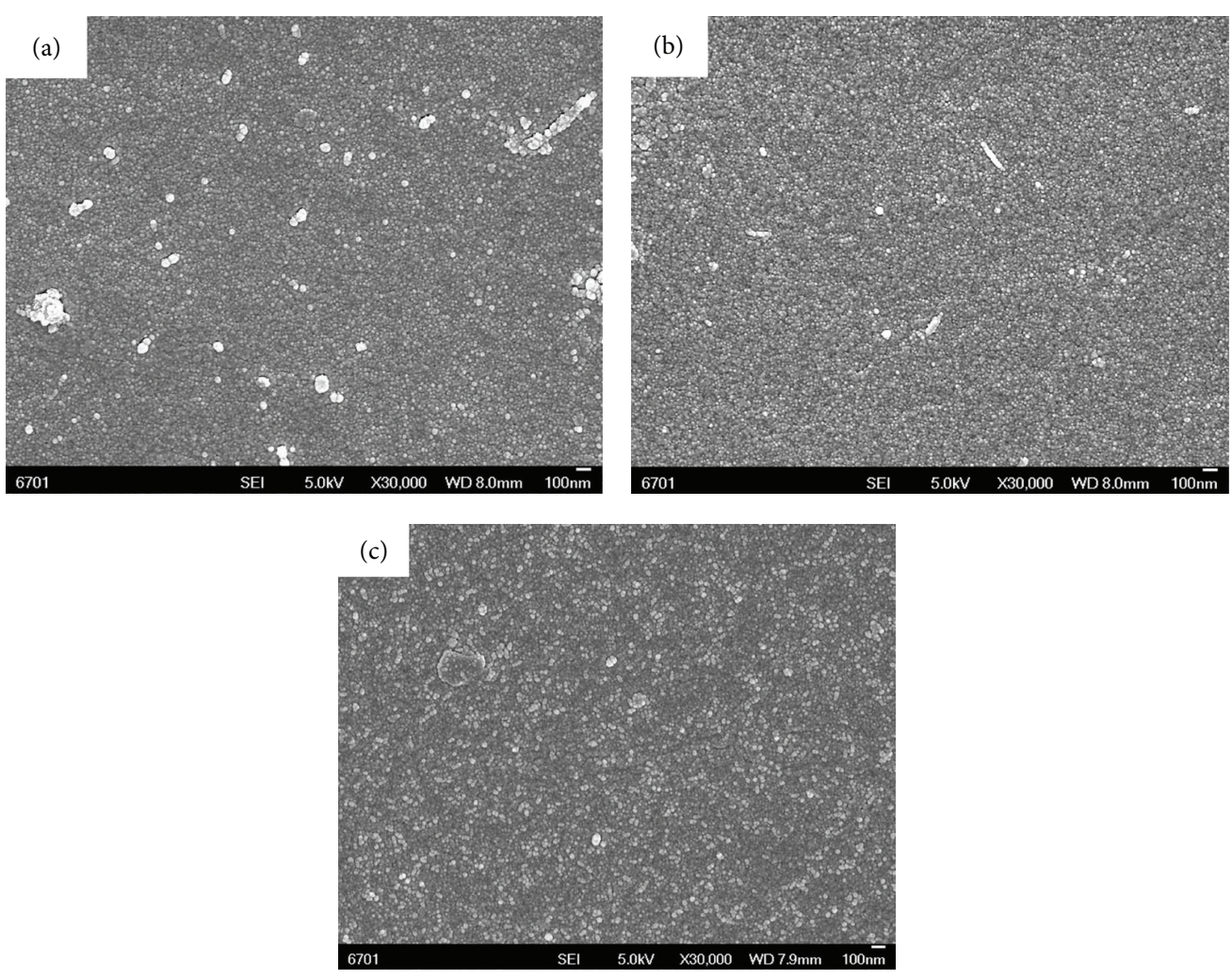

FIGURE 5: SEM images of M-PAANa prepared at different electric potential: (a) -0.08 , (b) -0.12 , and (c) $-0.2 \mathrm{~V}$.

\section{Conclusions}

In this study, polymer brushes were grafted on PES membrane by SI-eATRP method, and the results proved that the modified PES membrane has good hydrophilic and anticoagulation capability compared with those of pristine PES membrane. The water contact angle decreased from $84^{\circ}$ to $68^{\circ}$ and activated partial thromboplastin increased from
$51 \mathrm{~s}$ to $84 \mathrm{~s}$. Moreover, the polymerization can be controlled by reaction condition during SI-eATRP process, such as monomer concentration, electric potential, polymerization time, and modifier concentration.

\section{Competing Interests}

The authors declare that they have no competing interests. 

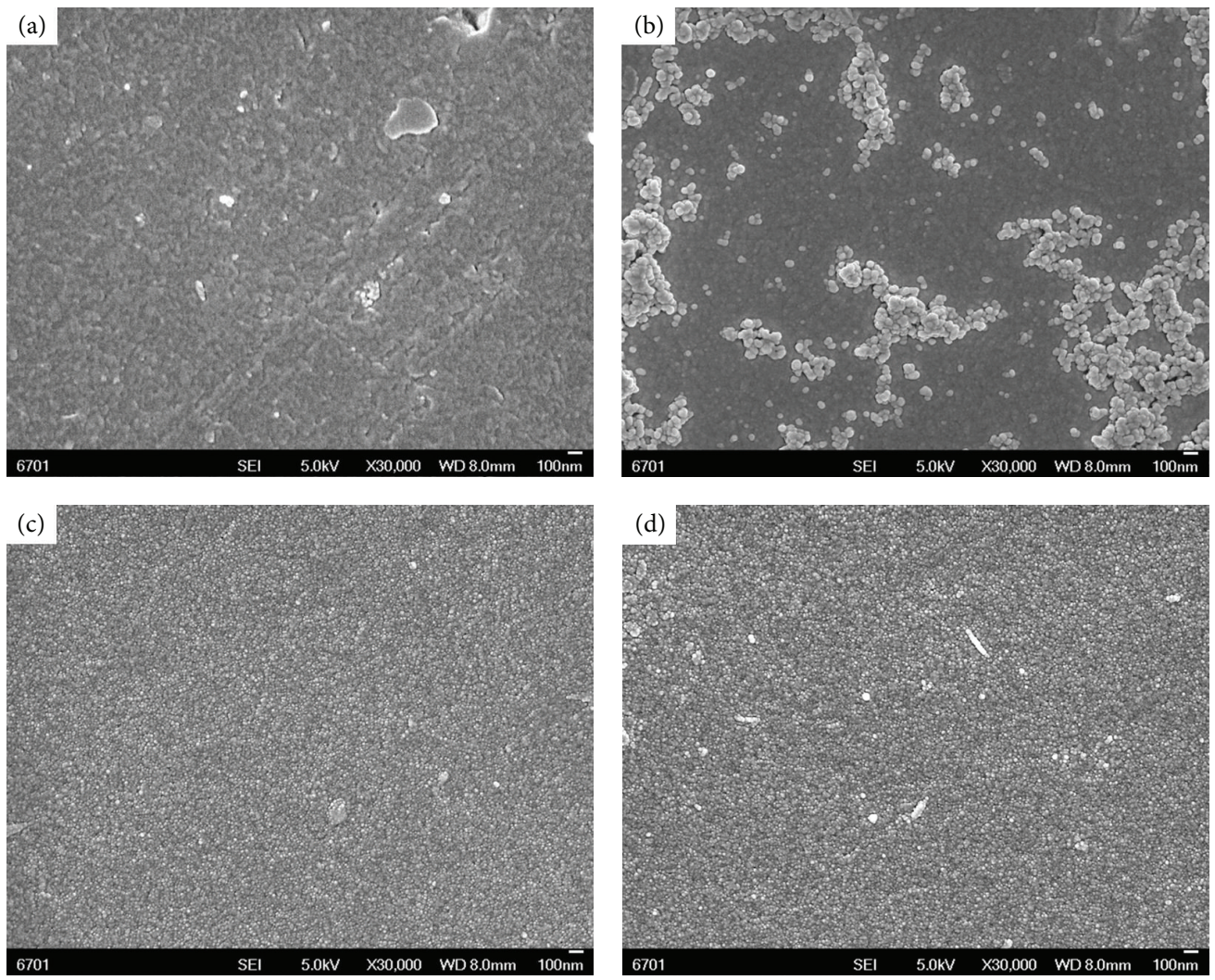

FIGURE 6: SEM images of M-PAANa prepared at different reaction times: (a) $10 \mathrm{~min}$, (b) $0.5 \mathrm{~h}$, (c) $1 \mathrm{~h}$, and (d) $8 \mathrm{~h}$.
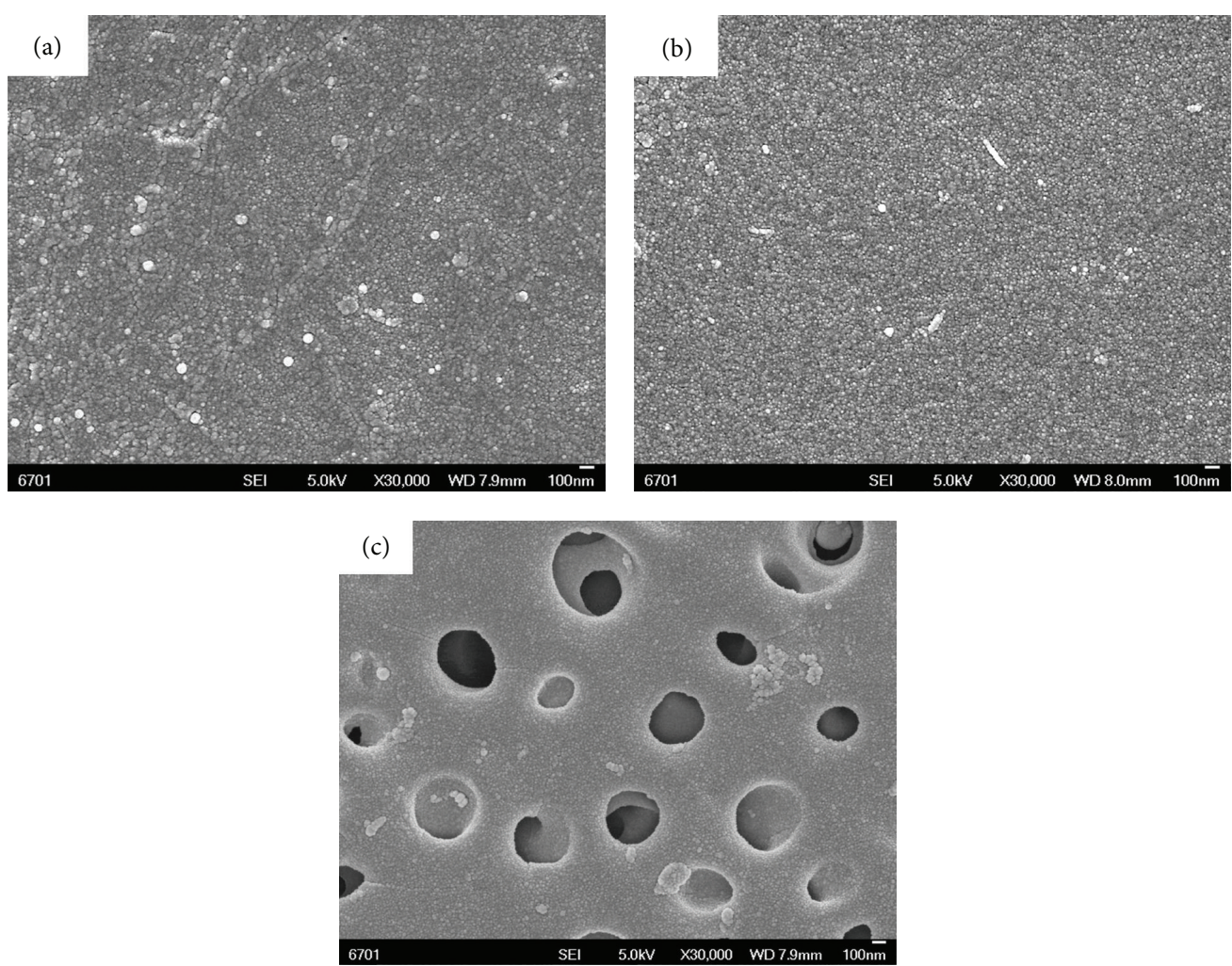

FIGURE 7: SEM images of M-PAANa prepared at different modifier concentrations: (a) 0.8, (b) 2, and (c) 5 wt.\%. 


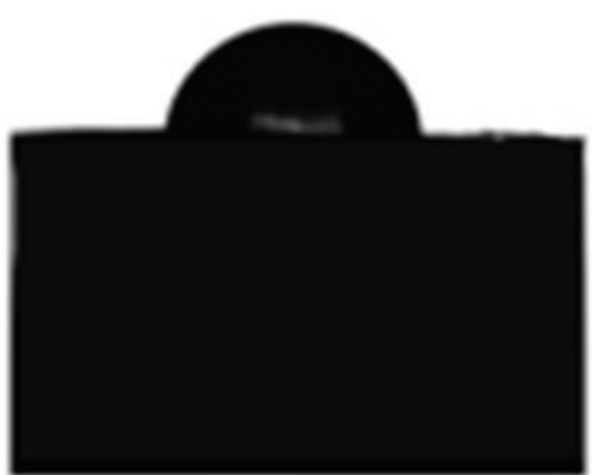

(a)

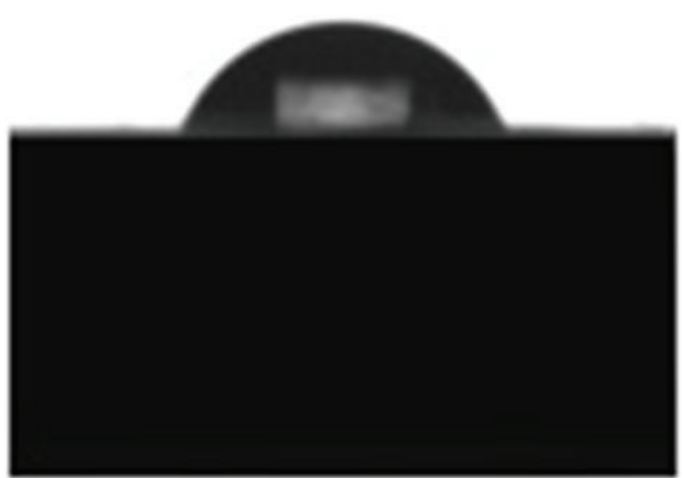

(b)

Figure 8: Water contact angle of (a) M-PES and (b) M-PAANa.

\section{References}

[1] T. Xiang, W.-W. Yue, R. Wang, S. Liang, S.-D. Sun, and C.S. Zhao, "Surface hydrophilic modification of polyethersulfone membranes by surface-initiated ATRP with enhanced blood compatibility," Colloids \& Surfaces B: Biointerfaces, vol. 110, pp. $15-21,2013$.

[2] Q. Wei and R. Haag, "Universal polymer coatings and their representative biomedical applications," Materials Horizons, vol. 2, no. 6, pp. 567-577, 2015.

[3] K. A. Heyries, L. J. Blum, and C. A. Marquette, "Direct poly(dimethylsiloxane) surface functionalization with vinyl modified DNA," Chemistry of Materials, vol. 20, no. 4, pp. 1251-1253, 2008.

[4] C. Zhao, Q. Wei, K. Yang, X. Liu, M. Nomizu, and N. Nishi, "Preparation of porous polysulfone beads for selective removal of endocrine disruptors," Separation \& Purification Technology, vol. 40, no. 3, pp. 297-302, 2004.

[5] X.-J. Huang, D. Guduru, Z.-K. Xu, J. Vienken, and T. Groth, "Blood compatibility and permeability of heparin-modified polysulfone as potential membrane for simultaneous hemodialysis and LDL removal," Macromolecular Bioscience, vol. 11, no. 1, pp. 131-140, 2011.

[6] F. Ran, S. Q. Nie, J. Li, B. H. Su, S. D. Sun, and C. S. Zhao, "Heparin-like macromolecules for the modification of anticoagulant biomaterials," Macromolecular Bioscience, vol. 12, no. 1, pp. 116-125, 2012.

[7] J. Y. Park, M. H. Acar, A. Akthakul, W. Kuhlman, and A. M. Mayes, "Polysulfone-graft-poly(ethylene glycol) graft copolymers for surface modification of polysulfone membranes," Biomaterials, vol. 27, no. 6, pp. 856-865, 2006.

[8] P.-S. Liu, Q. Chen, S.-S. Wu, J. Shen, and S.-C. Lin, "Surface modification of cellulose membranes with zwitterionic polymers for resistance to protein adsorption and platelet adhesion," Journal of Membrane Science, vol. 350, no. 1-2, pp. 387-394, 2010.

[9] C. Cheng, S. Li, W. F. Zhao et al., "The hydrodynamic permeability and surface property of polyethersulfone ultrafiltration membranes with mussel-inspired polydopamine coatings," Journal of Membrane Science, vol. 417-418, pp. 228-236, 2012.

[10] B. Kaeselev, J. Pieracci, and G. Belfort, "Photoinduced grafting of ultrafiltration membranes: comparison of poly(ether sulfone) and poly(sulfone)," Journal of Membrane Science, vol. 194, no. 2, pp. 245-261, 2001.
[11] D. Tyszler, R. G. Zytner, A. Batsch et al., "Reduced fouling tendencies of ultrafiltration membranes in wastewater treatment by plasma modification," Desalination, vol. 189, no. 1-3, pp.119-129, 2006.

[12] W. W. Yue, H. J. Li, T. Xiang et al., "Grafting of zwitterion from polysulfone membrane via surface-initiated ATRP with enhanced antifouling property and biocompatibility," Journal of Membrane Science, vol. 446, no. 11, pp. 79-91, 2013.

[13] J. S. Wang and K. Matyjaszewski, "Controlled/'living' radical polymerization. atom transfer radical polymerization in the presence of transition-metal complexes," Journal of the American Chemical Society, vol. 117, no. 20, pp. 5614-5615, 1995.

[14] J.-S. Wang and K. Matyjaszewski, "Controlled/'living' radical polymerization. Halogen atom transfer radical polymerization promoted by a $\mathrm{Cu}(\mathrm{I}) / \mathrm{Cu}(\mathrm{II})$ redox process," Macromolecules, vol. 28, no. 23, pp. 7901-7910, 1995.

[15] A. Mühlebach, S. G. Gaynor, and K. Matyjaszewski, "Synthesis of amphiphilic block copolymers by atom transfer radical polymerization (ATRP)," Macromolecules, vol. 31, no. 18, pp. 6046-6052, 1998.

[16] D. J. Siegwart, J. K. Oh, and K. Matyjaszewski, "ATRP in the design of functional materials for biomedical applications," Progress in Polymer Science, vol. 37, no. 1, pp. 18-37, 2012.

[17] J. Pyun, T. Kowalewski, and K. Matyjaszewski, "Synthesis of polymer brushes using atom transfer radical polymerization," Macromolecular Rapid Communications, vol. 24, no. 18, pp. 1043-1059, 2003.

[18] N. V. Tsarevsky and K. Matyjaszewski, “'Green’ atom transfer radical polymerization: from process design to preparation of well-defined environmentally friendly polymeric materials," ChemInform, vol. 38, no. 36, 2007.

[19] N. V. Tsarevsky, T. Pintauer, and K. Matyjaszewski, "Deactivation efficiency and degree of control over polymerization in ATRP in protic solvents," Macromolecules, vol. 37, no. 26, pp. 9768-9778, 2004.

[20] S. Coca, C. B. Jasieczek, K. L. Beers, and K. Matyjaszewski, "Polymerization of acrylates by atom transfer radical polymerization. Homopolymerization of 2-hydroxyethyl acrylate," Journal of Polymer Science, Part A: Polymer Chemistry, vol. 36, no. 9, pp. 1417-1424, 1998.

[21] M. Salami-Kalajahi, V. Haddadi-Asl, S. Rahimi-Razin, F. Behboodi-Sadabad, H. Roghani-Mamaqani, and M. Hemmati, 
"Investigating the effect of pristine and modified silica nanoparticles on the kinetics of methyl methacrylate polymerization," Chemical Engineering Journal, vol. 174, no. 1, pp. 368-375, 2011.

[22] N. Bortolamei, A. A. Isse, A. J. D. Magenau, A. Gennaro, and K. Matyjaszewski, "Controlled aqueous atom transfer radical polymerization with electrochemical generation of the active catalyst," Angewandte Chemie-International Edition, vol. 50, no. 48, pp. 11391-11394, 2011.

[23] T. S. Hansen, J. U. Lind, A. E. Daugaard, S. Hvilsted, T. L. Andresen, and N. B. Larsen, "Complex surface concentration gradients by stenciled 'electro click chemistry,"' Langmuir, vol. 26, no. 20, pp. 16171-16177, 2010.

[24] B. Li, B. Yu, W. T. Huck, F. Zhou, and W. M. Liu, "Electrochemically induced surface-initiated atom-transfer radical polymerization," Angewandte Chemie, vol. 124, no. 21, pp. 51825185, 2012.

[25] K. Matyjaszewski, H. Dong, W. Jakubowski, J. Pietrasik, and A. Kusumo, "Grafting from surfaces for 'everyone': ARGET ATRP in the presence of air," Langmuir, vol. 23, no. 8, pp. 4528-4531, 2007.

[26] D. Wang, X. Zhang, S. Nie et al., "Photoresponsive surface molecularly imprinted poly(ether sulfone) microfibers," Langmuir, vol. 28, no. 37, pp. 13284-13293, 2012.

[27] A. Nabe, E. Staude, and G. Belfort, "Surface modification of polysulfone ultrafiltration membranes and fouling by BSA solutions," Journal of Membrane Science, vol. 133, no. 1, pp. 5772, 1997. 

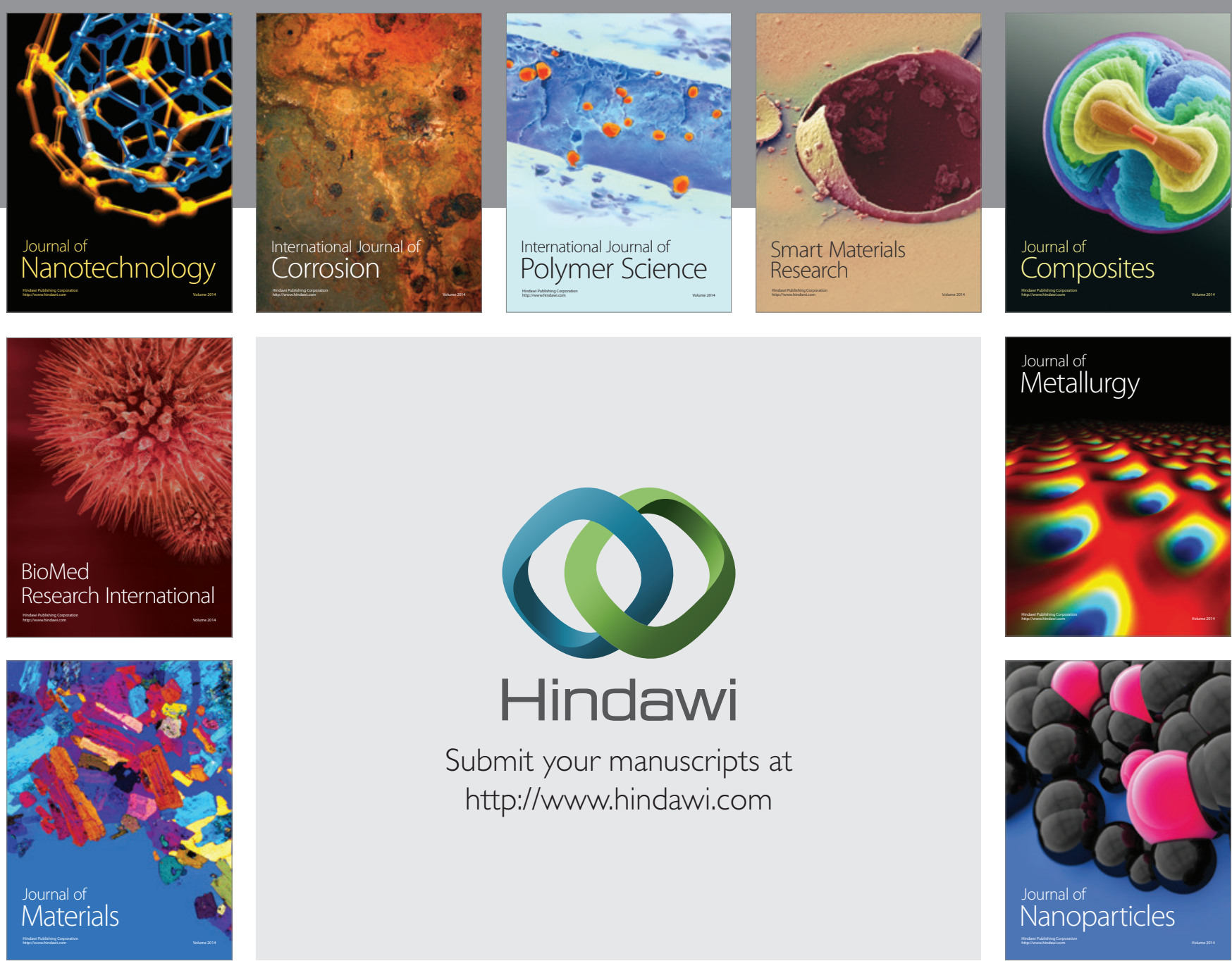

\section{Hindawi}

Submit your manuscripts at

http://www.hindawi.com

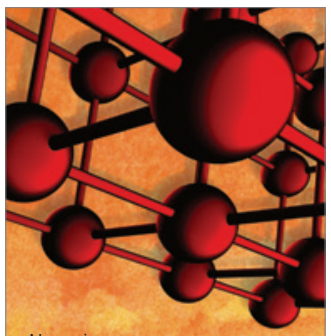

Materials Science and Engineering
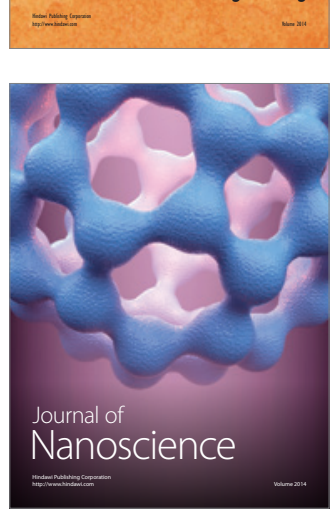
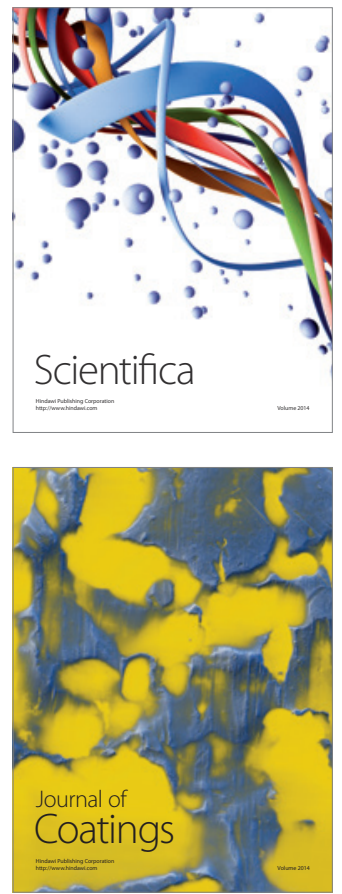
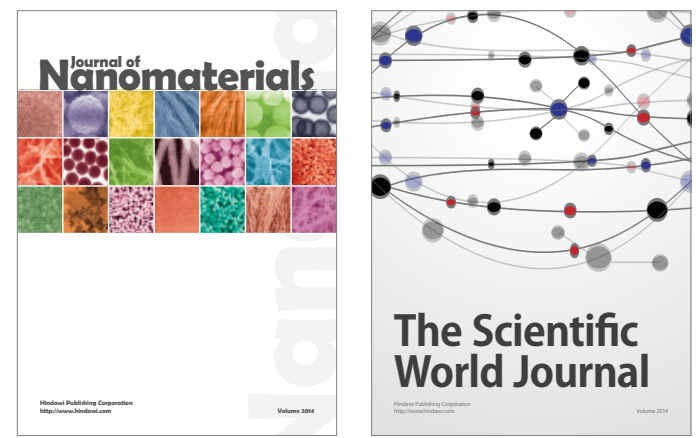

The Scientific World Journal
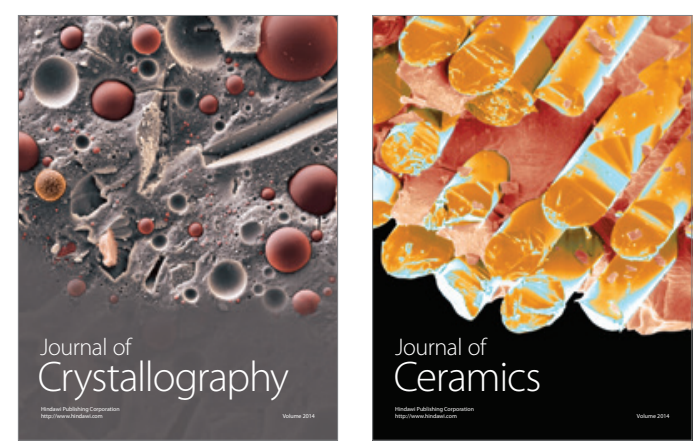
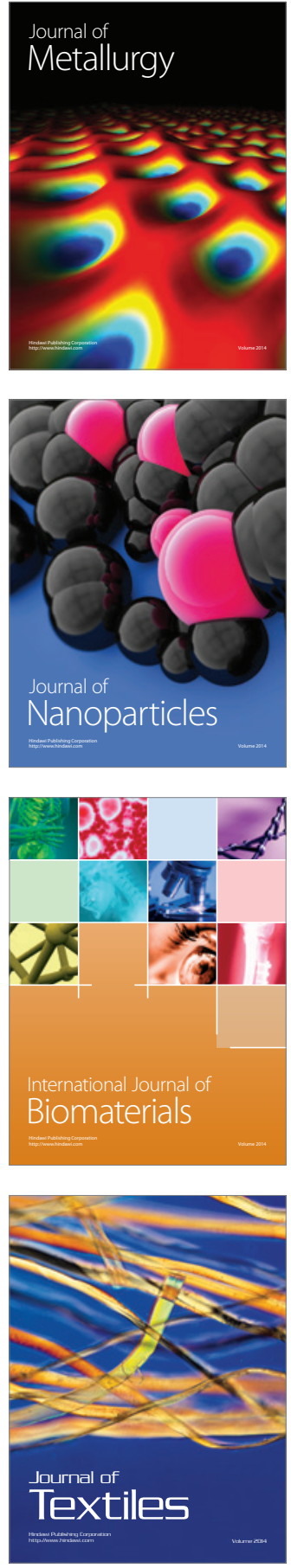